\title{
Analisis Pendapatan Asli Daerah dan Pengaruhnya terhadap Belanja Daerah di Provinsi Jambi
}

\author{
M. Zahari MS \\ Fakultas Ekonomi Universitas Batanghari \\ Correspondence email: m.zaharims@gmail.com
}

\begin{abstract}
Local Own Revenue (PAD) is an important source for the formation of regional finances to be allocated for regional expenditure. This study aims to analyze the potential sources of regional own-source revenues and their effects on capital expenditure in Jambi Province. This research was conducted in Jambi Province. The data used in the form of secondary data in the period 2010 -2018. The research method uses descriptive and quantitative methods. The analytical tool used in this study is a simple linear regression analysis and hypothesis testing with $t$ test. The results showed that the potential source of PAD came from local taxes, which provided the largest contribution in realizing PAD, while the smallest contribution was regional retribution. Empirically, the original regional income has a significant influence on regional expenditure, meaning that the higher the PAD income, the higher the regional expenditure for regional development activities and public services.
\end{abstract}

Keywords: Regional Finance, Regional Original Revenue, Regional Expenditure.

\section{PENDAHULUAN}

Penyelenggaraan otonomi daerah tersebut tentunya bersekuensi terhadap penyediaan dana terutama yang bersumber dari pengelolaan potensi yang ada pada daerah sendiri. Berdasarkan UU No. 33 Tahun 2004 dinyatakan, sumber-sumber pendanaan pelaksanaan pamerintah daerah, terdiri atas pendapatan asli daerah (PAD), Dana Perimbangan, dan lain-lain pendapatan yang sah. Pemerintahan daerah dalam mengalokasikan dana untuk kegiatan pembangunan daerah dan pelayanan publik pada setiap tahunnya dicantumkan ke dalam Anggaran Pendapatan dan Belanja Daerah (APBD). Pada APBD akan tergambar pos penerimaan daerah dan porsi belanja daerah yang dibutuh daerah untuk menyediakan sarana dan prasarana, baik untuk kelancaran pelaksanaan tugas pemerintahan maupun untuk fasilitas publik yang menunjang kegiatan produktif. Oleh karena itu, dalam upaya meningkatkan kualitas pelayanan publik, pemerintah daerah dalam penggunaan dana tersebut harus dilakukan secara transparan dan akuntabel. Belanja daerah merupakan pengeluaran pemerintah daerah yang digunakan untuk membiayai kegiatan pembangunan daerah (Wati dan Fajar, 2017). Berdasarkan Peraturan Pemerintah No. 58 Tahun 2005 Pasal 26 ayat (1), ditegaskan bahwa belanja daerah dipergunakan dalam rangka pelaksanaan urusan pemerintahan yang menjadi kewenangan provinsi atau kabupaten/kota yang terdiri dari urusan wajib dan urusan pilihan yang ditetapkan dengan ketentuan perundang-undangan, dan ayat (2) dinyatakan: belanja penyelenggaraan urusan wajib diprioritaskan untuk melindungi dan meningkatkan kualitas kehidupan masyarakat dalam upaya memenuhi kewajiban daerah yang diwujudkan dalam bentuk peningkatan pelayanan dasar, pendidikan, kesehatan, fasilitas sosial dan fasilitas umum yang layak serta mengembangkan sistem jaminan sosial. (http://www.djpk.kemenkeu.go.id/?p=460).

Pada umumnya belanja daerah memiliki kecenderungan untuk selalu naik (Wati dan Fajar, 2017). Kebutuhan belanja derah yang terus meningkat ini, tentunya harus ditopang dengan ada peningkatan penerimaan daerah terutama yang berasal dari pendapatan asli daerah (PAD). Untuk itu, perlu ada dorongan dari Pemerintah Daerah untuk meningkatkan kemampuannya dalam mengumpulkan pendapatan asli daerah (PAD) dengan maksud agar subsidi dari pemerintah pusat dapat dikurangi dan mengurangi beban APBN (Suparmoko, 2002). PAD yang merupakan sumber penerimaan dari daerah sendiri perlu ditingkatkan agar dapat membiayai penyelenggaraan pemerintahan dan kegiatan pembangunan daerah yang semakin meningkat (Orbaningsih, 2010).

Provinsi Jambi, sebagaimana provinsi lainnya yang ada di Indonesia dalam memenuhi kebutuhan akan pelayanan publik dan pembangunan daerah diperlukan dana yang tidak sedikit jumlahnya, baik yang berasal dari daerah sendiri atau bantuan dari pemerintah pusat berupa dana perimbangan. Selama tahun $2010-2018$, APBD Provinsi Jambi menunjukan trend peningkatan dari tahun 2010 sejumlah Rp. 1,84 triliun dan pada tahun 2018 sejumlah Rp. 4,51 triliun atau mengalami peningkatan rata-rata pertahun sebesar 13,09\%. Realisasi PAD menunjukkan peningkatan, yaitu dari sebesar Rp.686 miliar pada tahun 2010 dan menjadi sebesar Rp. 1,49 triliun pada tahun 2018 atau tumbuh rata-rata sebesar 11,48 persen pertahun. Peningkatan PAD ini belum sepenuhnya dapat diandalkan dalam menopang Anggaran Pendapatan dan Belanja Daerah (APBD) Provinsi Jambi, karena kontribusi PAD terhadap APBD relatif masih rendah bahkan cenderung menurun. Gambaran kontribusi PAD dan dana perimbangan terhadap APBD di Provinsi Jambi tahun 2010 - 2018 dapat dilihat pada tabel berikut: 
Tabel 1

Kontribusi PAD dan Dana Perimbangan terhadap APBD Provinsi Jambi Tahun 2010-2018

\begin{tabular}{|lr|r|r|r|r|}
\hline Tahun & PAD (Rp.Miliar) & Dana Perimbangan (Rp.Miliar) & APBD (Rp.Miliar) & Rasio (\%) AD/APBD & Rasio (\%) DP/APBD \\
\hline 2010 & 686 & 932 & 1.841 & 37,29 & \\
2011 & 984 & 1.075 & 2.432 & 40,47 & 50,63 \\
2012 & 995 & 1.332 & 3.287 & 30,29 & 44,21 \\
2013 & 1.063 & 1.489 & 3.577 & 29,74 & 40,54 \\
2014 & 1.281 & 1.514 & 3.679 & 34,82 & 4,65 \\
2015 & 1.241 & 1.419 & 3.604 & 34,44 & 41,16 \\
2016 & 1.273 & 1.549 & 3.742 & 35,26 & 39,37 \\
2017 & 1.580 & 2.766 & 4.583 & 34,48 & 41,35 \\
2018 & 1.494 & 2.703 & 4.515 & 33,10 & 59,41 \\
\end{tabular}

Sumber: BPS Provinsi Jambi, Statistik Keuangan Daerah, 2010 - 2018

Pada tahun 2010, PAD memberikan kontribusi sebesar 37,29 persen, tahun 2011 meningkat menjadi 40,47 persen, dan tahun 2018 PAD hanya mampu memberikan kontribusi terhadap APBD Provinsi Jambi sebesar 33,10 persen. Kondisi ini tentunya menyebabkan masih tingginya ketergantungan dana dari pemerintah pusat, karena rasio dana perimbangan terhadap APBD Provinsi Jambi hingga tahun 2018 mencapai 59,88 persen jauh melibihi rasio PAD yang hanya sebesar 33,10 persen. Kebutuhan belanja daerah yang terus meningkat ini, sedangkan penerimaan PAD kontribusinya cenderung menurun, sementara rasio dana perimbangan meningkat tajam. Kondisi ini menggambarkan masih tingginya ketergantungan Provinsi Jambi akan dana yang berasal pemerintah pusat. Permasalahan yang sering dirasakan pemerintah daerah dalam upaya meningkatkan sumber dana pada umumnya adalah berkaitan dengan penggalian sumber-sumber PAD yang belum optimal terutama yang berasal pajak daerah dan retribusi daerah. Berdasarkan fenomena diatas, maka yang menjadi permasalahan dalam penelitian ini adalah : (a) Sumber PAD yang mana paling potensial dalam meningkatkan pendapatan asli daerah di Provinsi Jambi. (b) Bagaimana pengaruh pendapatan asli daerah terhadap belanja daerah di Provinsi Jambi. Tujuan Penelitian adalah: (a) menganalisis sumber pendapatan asli daerah yang potensial di Provinsi Jambi. (b) menganalisis pengaruh pendapatan asli daerah terhadap belanja daerah Provinsi Jambi.

\section{METODE}

Jenis data yang digunakan dalam penelitian ini adalah data sekunder, yaitu data kuantitatif berupa penerimaan daerah, pendapatan asli daerah dan belanja daerah, yang dikumpulkan dalam kurun waktu (time series) tahun 2010 2018. Data diperoleh dari Dinas Pendapatan Pengelolaan Keuangan dan Asset Daerah (DPPKAD) Provinsi Jambi dan Badan Pusat Statistik (BPS) Jambi. Metode analisis data yang digunakan dengan pendekatan analisis deskriptif dan analisis kuantitatif dengan model regresi linier sederhana dengan bantuan program Eviews. Persamaan Regresi linier sederhana dalam penlitian diformulasikan sebagai berikut:

$\mathrm{BD}=\beta_{0}+\beta_{1} \mathrm{PAD}+\mathrm{e}$

Dimana: $\mathrm{BD}=$ Belanja Daerah; $\beta_{\mathrm{O}}=$ Konstanta; $\beta_{1}=$ Koefisien regresi; $\mathrm{PAD}=$ Pendapatan Asli Daerah; $\mathrm{e}=$ Error

Untuk dapat mengetahui baik atau tidaknya model regresi yang terestimasi dapat dilihat dari nilai koefisien determinasi $\left(\mathrm{R}^{2}\right)$. Koefisien determinasi ini mencerminkan seberapa besar variasi dari variabel terikat (dependen) dapat diterangkan oleh variabel bebas (independen). Pengujian hipotesis digunakan dengan uji t, yaitu untuk menguji tingkat signifikasi dari pengaruh PAD terhadap belanja daerah. Uji t ini dilakukan dengan cara membandingkan nilai t hitung dengan nilai t tabel pada derajat kebebasan atau Degree of freedom (df) yaitu n-k-1 (Sugiyono, 2011), dengan tingkat keyakinan 95 persen atau taraf signifikan sebesar $\alpha=5 \%(0,05)$. Kriterianya sebagai berikut:

a. $\mathrm{t}_{\text {hitung }} \geq \mathrm{t}$ tabel, maka Ho ditolak dan menerima Ha, artinya vartiabel independen berpengaruh signifikan terhadap variabel dependen.

b. $\mathrm{t}_{\text {hitung }}<\mathrm{t}$ tabel, maka Ho diterima dan menolak Ha, artinya vartiabel independen tidak berpengaruh signifikan terhadap variabel dependen.

\section{HASIL}

\section{Realisasi Pendapatan Asli Daerah}

Pendapatan Asli Daerah merupakan sumber pendapatan daerah yang penting dalam pembentukan keuangan daerah. Meningkatnya kemampuan keuangan daerah akan meningkatkan pula alokasi belanja daerah untuk kegiatan pembangunan daerah dan pelayanan publik. Untuk itu, pemerintah daerah akan terus berusaha untuk menggali dan mengelola sumber-sumber penerimaan daerah di berbagai sektor, diantaranya meningkatkan PAD melalui pajak daerah, retribusi daerah, hasil perusahaan milik daerah dan pengelolaan kekayaan daerah yang dipisahkan, dan lainlain PAD yang Sah. Gambaran realisasi mengenai kemampuan keuangan daerah yang bersumber dari pendapatan asli daerah di Provinsi Jambi dapat disimak pada tabel berikut ini: 
Tabel 2

Realisasi PAD Provinsi Jambi Tahun 2010-2018

\begin{tabular}{|c|c|c|c|c|c|c|c|c|c|c|}
\hline $\begin{array}{l}\text { Jenis Penerimaan } \\
\text { Pendapatan Asli Daerah (PAD) }\end{array}$ & $\begin{array}{l}2010 \\
686629\end{array}$ & $\begin{array}{l}2011 \\
984232\end{array}$ & $\begin{array}{c}2012 \\
995822\end{array}$ & \begin{tabular}{|l}
$\mathbf{2 0 1 3}$ \\
1063922
\end{tabular} & $\begin{array}{l}\mathbf{2 0 1 4} \\
1281239\end{array}$ & $\begin{array}{l}\mathbf{2 0 1 5} \\
1241237\end{array}$ & $\begin{array}{l}2016 \\
1273893\end{array}$ & $\begin{array}{l}\mathbf{2 0 1 7} \\
1580533\end{array}$ & $\begin{array}{l}\mathbf{2 0 1 8} \\
1494530\end{array}$ & $\begin{array}{c}\text { Rata-rata } \\
1,168,937.33\end{array}$ \\
\hline Pertumbuhan (\%) & - & 43.34 & 1.18 & 6.84 & 20.43 & $(3.12)$ & 2.63 & 24.07 & $(5.44)$ & 11.24 \\
\hline Pajak Daerah (PD) & 602355 & 838851 & 808258 & 841884 & 1010561 & 1010319 & 1062315 & 1316162 & 1272728 & $963,070.78$ \\
\hline Pertumbuhan (\%) & - & 39.26 & $(3.65)$ & 4.16 & 20.04 & $(0.02)$ & 5.15 & 23.90 & $(3.30)$ & 10.69 \\
\hline Rasio PD/PAD (\%) & 87.73 & 85.23 & 81.16 & 79.13 & 78.87 & 81.40 & 83.39 & 83.27 & 85.16 & 82.20 \\
\hline Retribusi Daerah (RD) & 43609 & 10195 & 12053 & 15364 & 14587 & 19337 & 20610 & 19865 & 21199 & $19,432.67$ \\
\hline Pertumbuhan (\%) & - & $(76.62)$ & 18.22 & 27.47 & $(5.06)$ & 32.56 & 6.58 & $(3.61)$ & 6.72 & 0.78 \\
\hline $\begin{array}{l}\text { Rasio RD/PAD (\%) } \\
\text { Hasil Perusahaan Milik Daerah dan }\end{array}$ & 6.35 & 1.04 & 1.21 & 1.44 & 1.14 & 1.56 & 1.62 & 1.26 & 1.42 & 1.33 \\
\hline Pengel olaan Kekayaan Daerah (HPKD) & 12443 & 21703 & 29984 & 26879 & 32219 & 33956 & 33503 & 29054 & 43059 & $28,475.22$ \\
\hline Pertumbuhan $(\%)$ & - & 74.42 & 38.16 & $(10.36)$ & 19.87 & 5.39 & $(1.33)$ & $(13.28)$ & 48.20 & 20.13 \\
\hline Rasio HPKD/PAD (\%) & 1.81 & 2.21 & 3.01 & 2.53 & 2.51 & 2.74 & 2.63 & 1.84 & 2.88 & 2.54 \\
\hline Lain-lain PAD yang Sah (LLP) & 28220 & 113482 & 145525 & 179795 & 223872 & 177625 & 157465 & 215452 & 157544 & $157,958.22$ \\
\hline Pertumbuhan (\%) & - & 302.13 & 28.24 & 23.55 & 24.52 & $(20.66)$ & $(11.35)$ & 36.83 & $(26.88)$ & 44.55 \\
\hline Rasio LLP/PAD (\%) & 4.11 & 11.53 & 14.61 & 16.90 & 17.47 & 14.31 & 12.36 & 13.63 & 10.54 & 13.92 \\
\hline
\end{tabular}

Sumber : Statistik Keuangan Daerah, BPS Provinsi Jambi 2010-2018 (diolah)

Pada Tabel 2, perkembangan realisasi pendapatan asli daerah Provinsi Jambi menunjukkan fluktuatif. Selama periode 2010 - 2018 penerimaan PAD Provinsi Jambi terjadi peningkatan rata-rata sebesar 11,24 persen pertahun. Realisasi pendapatan asli daerah Provinsi Jambi pada tahun 2018 tercatat sebesar 1,49 triliun rupiah atau meningkat sebesar 117,66 persen dibandingkan dengan tahun 2010 yang tercatat sebesar 686,62 miliar. Sumber PAD Provinsi Jambi pada tahun 2018 didominasi oleh Penerimaan Pajak Daerah yaitu sebesar 1,27 triliun rupiah (85,16 persen), Lain-lain PAD yang Sah sebesar 157,54 miliar rupiah (10,54 persen), dan sisanya berasal dari Hasil Pengelolaan Kekayaan Daerah yang dipisahkan sebesar 43,05 miliar rupiah (2,88 persen). Sementara, Retribusi Daerah yang merupakan bentuk penerimaan atas penggunaan fasilitas/pelayanan yang diberikan Pemerintah Provinsi Jambi kepada masyarakat memberikan sumbangan terkecil terhadap PAD yaitu sebesar 21,19 miliar rupiah (1,42 persen). Pendapatan Asli Daerah merupakan salah satu sumber pendapatan yang sangat penting bagi daerah dalam mengukur kemandirian keuangan daerah, karena pendapatan ini seluruhnya digali dan berasal dari daerah sendiri. Oleh karena itu, daerah mempunyai kewenangan penuh untuk memanfaatkan PAD sesuai dengan kebutuhan dan prioritas daerah.

\section{Realisasi Belanja Dearah}

Jumlah keseluruhan dana APBD, baik yang berasal dari PAD maupun dana perimbangan menjadi sumber belanja daerah dalam rangka melakukan pembangunan daerah guna mewujudkan peningkatan kesejahteraan masyarakat. Keberhasilan suatu daerah dalam mewujudkan peningkatan kesejahteraan masyarakat sangat tergantung pada kebijakan dari masing-masing pemerintah daerah. Kebijakan tersebut tercermin pada alokasi belanja daerah di APBD, yang terdiri dari belanja tidak langsung dan belanja langsung serta pembiayaan.

Tabel 3

Realisasi Belanja Daerah Provinsi Jambi Tahun 2010-2018

\begin{tabular}{|c|c|c|c|c|c|c|c|c|c|c|}
\hline \multirow{2}{*}{ Jenis Pengeluaran } & \multicolumn{9}{|c|}{ Realisasi Belanja Daerah (Rp. Juta) } & \multirow{2}{*}{ Rata-rata } \\
\hline & 2010 & 2011 & 2012 & 2013 & 2014 & 2015 & 2016 & 2017 & 2018 & \\
\hline Belanja Tidak Langsung & 672277 & 760339 & 1245497 & 1271926 & 1483116 & 1762391 & 1649327 & 2246421 & 2439437 & $1,503,415$ \\
\hline Pert (\%) & & 13.10 & 63.81 & 2.12 & 16.60 & 18.83 & $(6.42)$ & 36.20 & 8.59 & 19.11 \\
\hline Rasio BTL/BD & 36.51 & 31.26 & 37.89 & 35.56 & 40.31 & 48.90 & 48.77 & 49.01 & 54.03 & 42.47 \\
\hline Belanja Langsung & 815863 & 989902 & 1286101 & 1738815 & 1721517 & 1663175 & 1645157 & 1886521 & 2075707 & $1,535,862$ \\
\hline Pert (\%) & - & 21.33 & 29.92 & 35.20 & $(0.99)$ & (3.39) & $(1.08)$ & 14.67 & 10.03 & 13.21 \\
\hline Rasio BL/BD & 44.31 & 40.70 & 39.13 & 48.61 & 46.79 & 46.14 & 48.65 & 41.16 & 45.97 & 44.61 \\
\hline Belanja Pegawai & 53961 & 68132 & 84158 & 98334 & 90005 & 110945 & 122473 & 175425 & 188785 & 110,246 \\
\hline Pert (\%) & - & 26.26 & 23.52 & 16.84 & $(8.47)$ & 23.27 & 10.39 & 43.24 & 7.62 & 17.83 \\
\hline Rasio BP/BD & 2.93 & 2.80 & 2.56 & 2.75 & 2.45 & 3.08 & 3.62 & 3.83 & 4.18 & 3.13 \\
\hline Belanja Barang dan Jasa & 296041 & 403019 & 523197 & 702496 & 813453 & 760928 & 577145 & 815447 & 892933 & 642,740 \\
\hline Pert (\%) & - & 36.14 & 29.82 & 34.27 & 15.79 & $(6.46)$ & $(24.15)$ & 41.29 & 9.50 & 17.03 \\
\hline Rasio BBJ/BD & 16.08 & 16.57 & 15.92 & 19.64 & 22.11 & 21.11 & 17.07 & 17.79 & 19.78 & 18.75 \\
\hline Belanja Modal & 465860 & 518750 & 678747 & 937986 & 818059 & 791302 & 945539 & 895648 & 993989 & 782,876 \\
\hline Pert (\%) & - & 11.35 & 30.84 & 38.19 & $(12.79)$ & $(3.27)$ & 19.49 & $(5.28)$ & 10.98 & 11.19 \\
\hline Rasio BM/BD & 25.30 & 21.33 & 20.65 & 26.22 & 22.23 & 21.95 & 27.96 & 19.54 & 22.01 & 22.74 \\
\hline Pembiayaan Daerah & 353260 & 681825 & 755497 & 566331 & 474526 & 178679 & 87399 & 450544 & 0 & 394,229 \\
\hline Pert (\%) & - & 93.01 & 10.81 & $(25.04)$ & $(16.21)$ & $(62.35)$ & $(51.09)$ & 415.50 & $(100.00)$ & 33.08 \\
\hline Total Belanja & 1841400 & 2432067 & 3287095 & 3577072 & 3679159 & 3604245 & 3381884 & 4583486 & 4515144 & $3,433,506$ \\
\hline Pert (\%) & - & 32.08 & 35.16 & 8.82 & 2.85 & $(2.04)$ & (6.17) & 35.53 & (1.49) & 13.09 \\
\hline
\end{tabular}

Sumber : BPS, Statistik Keuangan Daerah, 2010 - 2018, diolah.

Berdasarkan Tabel 3 diketahui total belanja daerah di Provinsi Jambi pada tahun 2010 sebesar Rp.1,84 triliun dan meningkat tajam pada tahun 2016 hingga dua kali lipat yaitu mencapai sebesar Rp. 4,51 triliun. Secara rata-rata 
total belanja daerah di Provinsi Jambi dari tahun 2010 hingga tahun 2018 mengalami perkembangan yang cukup signifikan yaitu meningkat rata-rata sebesar 13,09 persen pertahun. Belanja langsung pada tahun 2010 sebesar Rp. 815,86 miliar dan tahun 2018 meningkat menjadi Rp. 2,07 triliun. Demikian pula dengan belanja tidak langsung mengalami peningakatan dari sebesar Rp. 672,27 miliar pada tahun 2010 menjadi Rp. 2,43 triliun pada tahun 2018. Dilihat dari prosentase peningkatan, belanja tidak langsung lebih tinggi prosentasenya dibandingkan dengan belanja langsung dan pembiayaan daerah. Belanja tidak langsung mengalami peningkatan rata-rata sebesar 19,11 persen pertahun dan belanja langsung meningkat rata-rata sebesar 13,21 persen pertahun, sedangkan pembiayaan daerah mengalami fluktuasi dan rata-rata sebesar 33,08 persen pertahun. Pada komponen belanja langsung, peningkatan tertinggi terjadi pada belanja pegawai yaitu rata-rata sebesar 17,83 persen pertahun dan belanja barang dan jasa ratarata sebesar 17,03 persen pertahun, sedangkan belanja modal terendah peningkatannya yaitu rata-rata sebesar 11,19 persen pertahun.

Alokasi belanja daerah terbesar terserap untuk belanja langsung yaitu mencapai rata-rata sebesar 44,61 persen pertahun, sedang belanja tidak lansung sebesar 42, 47 persen pertahun. Dilihat dari belanja langsung, terbesar dialokasikan untuk belanja modal yaitu rata-rata sebesar 22,74 persen pertahun dan yang terendah untuk keperluan belanja pegawai sebesar 3,13 persen pertahun. Perbedaan besarnya alokasi masing-masing belanja daerah ini tidak terlepas dari adanya perbedaan potensi, kondisi dan kebijakan prioritas pembangunan yang dilakukan oleh pemerintah daerah. Semakin banyak potensi sumber-sumber penerimaan daerah sendiri yang dapat digali akan semakin besar ketersediaan alokasi belanja daerah yang dapat dimanfaatkan untuk penyediaan fasilitas publik dan kegiatan pembangunan daerah. Peningkatan belanja daerah ini ditopang dengan kemampuan keuangan daerah yang cukup sehingga berbagai kegiatan pembangunan daerah untuk penyediaan fasilitas publik seperti fasilitas kesehatan dan pendidikan serta pemberdayaan ekonomi masyarakat dapat diperbaiki dan ditingkatkan.

\section{Pengaruh PAD terhadap Belanja Daerah}

Untuk mengetahui pengaruh Pendapatan Asli Daerah terhadap Belanja Daerah di Provinsi Jambi, maka akan dianalisis dengan menggunakan alat analisis regresi linier sederhana, determinasi, dan pengujian hipotesis dengan menggunakan uji t (parsial). Hasil estimasi dengan bantuan program Eviews terlihat pada tabel 4 berikut ini:

Tabel 4

Hasil Estimasi

\begin{tabular}{|c|c|c|c|c|}
\hline Variable & Coefficient & Std. Error & t-Statistic & Prob. \\
\hline $\mathrm{C}$ & -117.4807 & 456.8474 & -0.257155 & 0.8045 \\
\hline PAD & 3.037790 & 0.381601 & 7.960640 & 0.0001 \\
\hline R-squared & 0.900528 & Mean dependent var & & 3433.506 \\
\hline Adjusted R-squared & 0.886318 & S.D. dependent var & & 877.8016 \\
\hline S.E. of regression & 295.9662 & Akaike info criterion & & 14.41150 \\
\hline Sum squared resid & 613171.8 & Schwarz criterion & & 14.45533 \\
\hline Log likelihood & -62.85174 & Hannan-Quinn criter. & & 14.31692 \\
\hline F-statistic & 63.37179 & Durbin-Watson stat & & 1.849364 \\
\hline Prob(F-statistic) & 0.000094 & & & \\
\hline
\end{tabular}

Sumber: data olahan

\section{Persamaan Regresi Linier Sederhana}

Berdasarkan hasil estimasi dapat diketahui nilai koefisien regresi sebagai berikut:

$\mathrm{BD}=\beta_{0}+\beta_{1} \mathrm{PAD}+\mathrm{e}$

$\mathrm{BD}=-117,4807+3,0378 \mathrm{PAD}+\mathrm{e}$

Persamaan hasil regresi ini dapat maknai:

a. Konstanta $(B D)=-117.481$.

Artinya bahwa pada saat variabel PAD dalam keadaan konstan, maka belanja daerah (BD) di Provinsi Jambi menurun sebesar 117,4807, dengan asumsi faktor-faktor lain dianggap konstan atau nol.

b. Pendapatan Asli Daerah (PAD) = 3,0378.

Artinya apabila terjadi kenaikan pada PAD dalam satu satuan, maka dapat meningkatkan belanja daerah sebesar 3,0378, dimana faktor lainnya dalam keadaan konstan atau nol.

Dilihat dari koefisien determinasi ( $R$ Square) adalah sebesar 0,9005. Angka ini menunjukkan variabel PAD memiliki kemampuan menjelaskan variabel belanja daerah sebesar 90,05\%, sedangkan sisanya sebesar 9,95\% dijelaskan oleh variabel-variabel lain yang tidak termasuk dalam model penelitian ini. Pengujian hipotesis dilakukan dengan uji t yaitu membandingkan uji $t$ hitung dengan $t$ tabel. Hasil estimasi menunjukkan nilai $t$ hitung sebesar 7,960640, dan nilai $\mathrm{t}$ tabel pada $\mathrm{df}=7$ dengan tingkat signifikan $95 \%$ atau $\square=5 \%(0,05)$ maka diperoleh 
$\mathrm{t}$ tabel sebesar 2,36462, maka $\mathrm{t}$ hitung $>\mathrm{t}$ tabel atau signifikansi 0,0001 $<0,05$ yang menunjukkan hipotesis nol (Ho) ditolak dan hipotesis alternative (Ha) diterima, artinya Pendapatan Asli Daerah berpengaruh signifikan terhadap belanja daerah di Provinsi Jambi.

\section{Pembahasan}

Berdasarkan hasil penelitian ini telah dapat menjawab hipotesis yang diajukan yaitu "Pendapatan Asli Daerah berpengaruh signifikan terhadap Belanja Daerah di Provinsi Jambi". Kenyataan ini mengindikasikan PAD sangat berperan penting dalam meningkatkan penyediaan dana untuk anggaran belanja daerah di Provinsi Jambi. Temuan ini menjelaskan bahwa kemampuan daerah dalam menghasilkan pendapatan daerah memiliki pengaruh yang menentukan bagi daerah untuk mendukung atau membiayai seluruh pengeluaran yang berhubungan dengan alokasi belanja daerah yang dicantum dalam APBD. Dengan kata lain sebagian besar pengeluaran atas belanja daerah ditentukan oleh penerimaan yang berasal dari pendapatan asli daerah (PAD). Temuan ini juga dapat diartikan jika semakin tinggi kemampuan daerah dalam menghasilkan pendapatan asli daerah dari potensi yang ada di daerah, maka akan semakin besar kemampuan daerah tersebut dalam mendukung belanja daerahnya, namun sebaliknya jika semakin rendah kemampuan daerah dalam menghasilkan penerimaan daerah yang berasal dari pendapatan asli daerah, maka juga akan menurunkan kemampuan daerah tersebut mengalokasi anggaran belanja daerah yang telah direncanakan untuk kegaiatan pembangunan daerah dan pelayanan publik. Hasil Penelitian ini sejalan dengan penelitian yang dilakukan Wati dan Fajar (2017) yang menyimpulkan Pendapatan asli daerah memiliki pengaruh yang signifikan terhadap belanja daerah.). Penelitian Dermawan (2017) menemukan, Pendapatan asli daerah berpengaruh signifikan terhadap belanja daerah. Hasil penelitian Rahmawati, et al. (2015) menemukan, Pendapatan asli daerah berpengaruh signifikan terhadap belanja daerah. Demikian pula hasil penelitian Rahim (2008) menjelaskan Secara umum, semakin tinggi kontribusi PAD dan semakin tinggi kemampuan daerah untuk membiayai kemampuannya sendiri akan menunjukkan kinerja keuangan daerah yang positif. Peningkatan PAD ini dapat juga mengurangi ketergantungan sumber dana dari pemerintah pusat berupa dana perimbangan. Apabila kemampuan PAD dalam rangka menunjang kemampuan keuangan daerah masih relatif rendah, maka akan menyebabkan ketergantungan daerah terhadap dana pemerintah pusat masih cukup tinggi, akibatnya kemandirian daerah sebagai impelementasi dari asas desentralisasi dalam pelaksanaan otonomi daerah akan sulit dicapai sepenuhnya.

\section{SIMPULAN}

1. Pajak daerah merupakan sumber penerimaan yang potensial dalam merealisasi PAD, sedang retribusi daerah relatif sangat tidak potensial dalam meningkatkan pemerimaan PAD di Provinsi Jambi.

2. Di Provinsi Jambi, Pendapatan asli daerah berpangaruh signifikan terhadap belanja daerah, artinya semakin tinggi penerimaan PAD akan semakin meningkatan belanja daerah.

\section{DAFTAR PUSTAKA}

Dermawan, Wildan Dwi. 2017. Pengaruh Pendapatan Asli Daerah (PAD) Terhadap Belanja Daerah (Studi Kasus di Pemerintah Daerah Kabupaten/Kota Provinsi Jawa Barat). Jurnal Ilmiah EDUKASI Volume. 5 Nomor 2, November 2017

Kementerian Keuangan Dirjend Perimbangan Keuangan. Peraturan Pemerintah Republik Indonesia Nomor 58 Tahun 2005 Tentang Pengelolaan Keuangan Daerah. http://www.djpk.kemenkeu.go.id/?p=460.

Orbaningsih, Dwi. 2010. Penggalian Potensi Pendapatan Asli Daerah di Kota Malang. Jurnal akuntansi indonesia vol. 6 , no. 1 , februari $2010,1-12$

Rahim, Syamsuri. 2008. Analisis Kemampuan Pendapatan Asli Daerah Dalam Membiayai Belanja Daerah. Jurnal Ichsan Gorontalo. Vol. 3 No. 2, Mei - Juli 2008.

Rahmawati, Luluk Atika dan Bambang Suryono. (2015). Flypaper Effect Dana Alokasi Umum dan Pendapatan Asli Daerah terhadap Belanja Daerah. Jurnal Ilmu dan Riset Akuntansi. Vol.4, No.9: 1-20.

Sugiyono, 2011. Metode Penelitian Kuantitatif dan Kualitatif dan R\&D, Alfabeta, Bandung.

Suparmoko, 2002. Ekonomi Publik: Untuk Keuangan dan Pembangunan Daerah. Edisi Pertama, Penerbit Andi, Yogyakarta.

Undang-Undang Nomor 33 Tahun 2004 tentang Perimbangan Keuangan antara Pemerintah Pusat dan Pemerintah Daerah. Lembaran Negara Republik IndonesiaTahun 2004 Nomor 126.

Wati, Masayu Rahma dan Catur Martian Fajar. 2017. Pengaruh Pendapatan Asli Daerah dan Dana Perimbangan Terhadap Belanja Daerah Kota Bandung. Jurnal Kajian Akuntansi, Vol 1, (1), 2017, 63-76 